PYTHAGORAS: Jurnal Pendidikan Matematika

Volume 11 - Nomor 2, Desember 2016, (123-135)

Available online at: http://journal.uny.ac.id/index.php/pythagoras

\title{
Keefektifan Problem Posing dan Problem Solving Ditinjau dari Ketercapaian Kompetensi, Metode, dan Sikap Matematis
}

\author{
Ahmad Nasrullah $^{1} *$, M. Marsigit ${ }^{2}$ \\ ${ }^{12}$ Program Studi Pendidikan Matematika, Universitas Negeri Yogyakarta Jalan Colombo No 1, \\ Karangmalang, Yogyakarta 55281 \\ * Korespondensi Penulis. Email: anahmadnasr@gmail.com
}

\begin{abstract}
Abstrak
Penelitian ini bertujuan untuk mendeskripsikan dan membandingkan keefektifan pembelajaran problem posing dan problem solving ditinjau dari ketercapaian kompetensi dasar, metode matematis, dan sikap matematis siswa SMA. Penelitian yang digunakan adalah penelitian eksperimen semu dengan desain Nonequivalent (Pretest and Posttest) group design. Populasi dalam penelitian ini adalah siswa kelas X SMA Negeri 1 Sakra Lombok Timur yang terdiri dari tujuh kelas. Dari tujuh kelas tersebut, dipilih secara acak dua kelas sebagai kelas eksperimen. Hasil penelitian menunjukkan bahwa 1) pendekatan problem posing dan problem solving efektif ditinjau dari ketercapaian kompetensi dasar, metode matematis, dan sikap matematis siswa SMA;2) ada perbedaan keefektifan pendekatan problem posing dan problem solving ditinjau dari ketiga variabel dependen secara simultan;3) pendekatan problem solving lebih efektif dibandingkan dengan pendekatan problem posing ditinjau dari ketercapaian kompetensi dasar dan kemampuan metode matematis;4) tidak ada perbedaan keefektifan kedua pendekatan pembelajaran ditinjau dari sikap matematis siswa SMA.
\end{abstract}

Kata Kunci: pendekatan problem posing, problem solving, ketercapaian kompetensi dasar, metode matematis, sikap matematis siswa.

\section{The Effectiveness of Problem Posing and Problem Solving in Terms of Basic Competence Attainment, Mathematical Method, and Mathematical Attitude}

\begin{abstract}
This study aims to describe and compare the effectiveness of problem posing and problem solving approaches in terms of mathematics basic competence attainment, mathematical method, and mathematical attitude of senior high school students. This study was a quasi-experimental study using the nonequivalent pretest and posttest group design. The population was the X grade students of State Senior High School 1 of Sakra Lombok Timur that consisted of seven classes. The sample was two classes selected randomly from all Year X classes. The results of the study are (1) problem posing and problem solving approaches are effective in terms of the mathematics basic competence attainment, mathematical method and mathematical attitude of Senior High School students; (2) there is a different effect of problem posing and problem solving approaches on all dependent variables simultaneously; (3) problem solving approach is more effective than problem posing in terms of the basic competence attainment and mathematical method; (4) there is no different effect of problem posing and problem solving approaches in terms of student mathematical attitude.
\end{abstract}

Keywords: problem posing approach, problem solving approach, mathematics basic competence attainment, mathematical method, mathematical attitude.

How to Cite: Nasrullah, A., \& Marsigit, M. (2016). Keefektifan problem posing dan problem solving ditinjau dari ketercapaian kompetensi, metode, dan sikap matematis. PYTHAGORAS: Jurnal Pendidikan Matematika, 11(2), 123-135. doi:http://dx.doi.org/10.21831/pg.v11i2.11180

Permalink/DOI: http://dx.doi.org/10.21831/pg.v11i2.11180 


\section{Pythagoras, 11 (2), Desember 2016 - 124}

Ahmad Nasrullah, M. Marsigit

\section{PENDAHULUAN}

Dalam Peraturan Kementerian Pendidikan Nasional Nomor 22 Tahun 2006 tanggal 23 Mei 2006 disebutkan bahwa pendidikan nasional yang berdasarkan Pancasila dan UndangUndang Dasar Negara Republik Indonesia Tahun 1945 berfungsi mengembangkan kemampuan dan membentuk watak serta peradaban bangsa yang bermartabat dalam rangka mencerdaskan kehidupan bangsa, bertujuan untuk mengembangkan potensi peserta didik agar menjadi manusia yang beriman dan bertakwa kepada Tuhan Yang Maha Esa, berakhlak mulia, sehat, berilmu, cakap, kreatif, mandiri, dan menjadi warga negara yang demokratis dan bertanggung jawab. Untuk mengemban fungsi tersebut pemerintah menyelenggarakan suatu sistem pendidikan nasional sebagaimana tercantum dalam Undang-Undang Nomor 20 Tahun 2003 tentang Sistem Pendidikan Nasional.

Sebagai implementasi dari UndangUndang Nomor 20 Tahun 2003 tentang Sistem Pendidikan Nasional ini maka dikeluarkan Peraturan Pemerintah Nomor 19 Tahun 2005 tentang Standar Nasional Pendidikan yang mencakup standar isi, standar proses, standar kompetensi lulusan, standar pendidik dan tenaga kependidikan, standar sarana dan prasarana, standar pengelolaan, standar pembiayaan dan standar penilaian pendidikan. Selanjutnya pada tahun 2006, pemerintah mengeluarkan Permendiknas Nomor 22 Tahun 2006 tentang standar isi. Di dalam peraturan ini disebutkan bahwa mata pelajaran matematika ditingkat Sekolah Menengah Atas (SMA) bertujuan agar peserta didik memiliki kemampuan sebagai berikut: (1) memahami konsep matematika, menjelaskan keterkaitan antarkonsep dan mengaplikasikan konsep atau algoritma, secara luwes, akurat, efisien, dan tepat, dalam peme-cahan masalah; (2) menggunakan penalaran pada pola dan sifat, melakukan manipulasi matematika dalam membuat generalisasi, menyusun bukti, atau menjelaskan gagasan dan pernyataan matematika; (3) memecahkan masalah yang meliputi kemampuan memahami masalah, merancang model matematika, menyelesaikan model dan menafsirkan solusi yang diperoleh; (4) mengomunikasikan gagasan dengan simbol, tabel, diagram, atau media lain untuk memperjelas keadaan atau masalah; dan (5) memiliki sikap menghargai kegunaan matematika dalam kehidupan, yaitu memiliki rasa ingin tahu, perhatian, dan minat dalam mempelajari matematika, serta sikap ulet dan percaya diri dalam pemecahan masalah.

Selain menekankan pentingnya kemampuan atau kompetensi dasar, tujuan kurikulum pendidikan matematika di Indonesia saat ini juga menekankan pentingnya kemampuan berpikir (Marsigit, 2007, p.12). Bahkan para ahli di berbagai negara sudah mulai menyadari pentingnya memasukkan kemampuan berpikir matematis ke dalam kurikulum (Khalid, 2007, p.169; Marsigit, 2009, pp.6-10)

Berpikir yang baik lebih penting daripada sekedar mempunyai jabawan yang benar. Seseorang yang mempunyai cara berpikir yang baik, dalam arti bahwa cara berpikirnya dapat digunakan untuk menghadapi suatu fenomena baru, akan dapat menemukan pemecahan dalam menghadapi persoalan lain. Sementara itu, seorang pelajar yang sekedar menemukan jawaban benar belum pasti dapat memecahkan persoalan yang baru karena mungkin ia tidak mengerti bagaimana menemukan jawaban itu (Suparno, 1997, p.65). Selain itu, pendapat Stacey (2007, p.39) mengatakan bahwa berpikir matematis sangat penting untuk tiga hal, yaitu: (1) berpikir matematis merupakan tujuan penting dari sekolah, (2) berpikir matematis merupakan hal penting untuk belajar matematika, dan (3) berpikir matematis merupakan hal penting untuk mengajar matematika.

Khalid (2007, p.169) mengatakan bahwa berpikir matematis merupakan metode matematis dalam berpikir yang digunakan untuk menyelesaikan setiap masalah dalam kehidupan seharihari, termasuk di sekolah. Berpikir matematis didefinisikan sebagai mengaplikasikan teknik matematis, konsep, atau proses secara inplisit dan ekspilisit dalam penyelesaian masalah. Adapun Katagiri (2007, p.116) mengatakan bahwa kemampuan berpikir matematis adalah kemampuan seseorang ketika menghadapi suatu masalah untuk memutuskan atau memilih perangkat psikologis mana yang akan digunakannya untuk menyelesaikan masalah tersebut. Lebih lanjut dikatakan bahwa berpikir matematis bisa dibagi menjadi tiga kategori yaitu: (1) berpikir matematis yang terkait sikap matematis, (2) berpikir matematis yang terkait dengan metode matematis, dan (3) berpikir matematis yang terkait dengan konten matematis.

Berpikir matematis yang terkait sikap matematis mempunyai empat komponen yaitu: (1) berusaha memahami berbagai persoalan, 
tujuan dan substansi masalah matematika secara mandiri, (2) berusaha mengambil tindakan logis, (3) berusaha menyatakan berbagai hal dengan jelas dan ringkas, dan (4) berusaha mencari berbagai hal yang lebih baik. (Katagiri, 2007, pp.148-151). Sikap matematis ditunjukkan dengan indikator adanya rasa senang dan ikhlas untuk mempelajari matematika, sikap yang mendukung untuk mempelajari matematika, pengetahuan yang cukup untuk mempelajari matematika, rasa ingin tahu, kemauan untuk bertanya, kemauan untuk memperoleh keterampilan dan pengalaman matematis (Marsigit, 2009, p.2).

Berpikir matematis yang terkait dengan metode matematis terdiri dari: (1) berpikir induktif, (2) berpikir analogis, (3) berpikir deduktif, (4) berpikir integratif, (5) berpikir mengembangkan, (6) berpikir abstrak (abstraksi, konkretisasi, idealisasi, dan klarifikasi keadaan), (7) simplifikasi, (8) generalisasi, (9) spesialisasi, (10) simbolisasi, dan (11) berpikir yang diungkapkan dengan bilangan, kuantitas, dan gambar (Katagiri, 2007, pp.117-118).

Berdasarkan hasil observasi dan wawancara dengan guru matematika di SMAN 1 Sakra Kabupaten Lombok Timur NTB, hampir sebagian besar proses pembelajaran matematika di kelas selama ini masih tergantung dan didominasi oleh guru. Hal ini menyebabkan pembelajaran bersifat monoton yang berakibat rendahnya motivasi belajar siswa dan minimnya tingkat ketercapaian kompetensi dasar siswa sebagaimana bisa dilihat pada Tabel 1 . Siswa mengalami kesulitan dalam menjawab soal yang tidak sama persis dengan contoh yang diberikan atau contoh soal yang ada di dalam buku mata pelajaran matematika. Selain itu siswa juga hanya diberikan pertanyaan-pertanyaan tertutup sehingga tidak menimbulkan motivasi kepada siswa untuk mencari alternatif jawaban yang lain. Kelas masih didominasi oleh guru dan siswa-siswa dengan kemampuan tinggi sementara siswa dengan kemampuan menengah ke bawah cenderung pasif.

Tabel 1. Ketercapaian Kompetensi Dasar Materi Pokok Trigonometri Kelas X SMA Negeri 1 Sakra

\begin{tabular}{ccc}
\hline NO & Kelas & Nilai Rata-rata \\
\hline 1 & X-3 & 29,1 \\
2 & X-4 & 28,9 \\
3 & X-5 & 34,5 \\
4 & X-6 & 35,2 \\
5 & X-7 & 38,1 \\
\hline
\end{tabular}

Sumber: Guru Matematika SMAN 1 Sakra

Rendahnya mutu pendidikan Indonesia terutama pendidikan matematika tidak bisa lepas dari kualitas pembelajaran di dalam kelas. Untuk meningkatkan kualitas pembelajaran di dalam kelas, guru dituntut untuk mencari inovasiinovasi pembelajaran sehingga dapat meningkatkan kualitas pembelajaran, terutama dalam rangka meningkatkan kemampuan berpikir, sikap, dan ketercapaian kompetensi dasar siswa.

Namun, fakta di lapangan bahwa guru mengalami tantangan dalam menerapkan pembelajaran yang berorientasi pada kemampuan berpikir matematis tingkat tinggi. Berdasarkan hasil penelitian Jailani \& Retnawati (2016, p. 8) bahwa tantangan guru dalam mengembangkan pembelajaran yang mengasah kemampuan berpikir tingkat tinggi (HOTS) adalah guru mengalami kesulitan dalam mengembangkan materi dan media pembelajaran dikarenakan belum memiliki pengetahuan yang memadai tentang pembelajaran yang menumbuhkembangkan kemampuan berpikir tingkat tinggi.

Dalam hal ini, Marsigit (2011, p.1) mengatakan bahwa untuk mengembangkan sikap dan kreativitas dalam pembelajaran matematika, guru perlu mengembangkan inovasi dalam mengajar matematika. Guru harus mengem-bangkan berbagai jenis gaya mengajar yaitu metode mengajar yang bervariasi dan fleksibel, metode diskusi, metode berbasis masalah, interaksi kelas yang bervariasi, dan penggunaan pendekatan realistik atau kontekstual. Lebih lanjut dijelaskan bahwa untuk mengembangkan sikap dan kreativitas, guru perlu pemahaman yang mendalam tentang hakikat matematika sekolah, hakikat belajar matematika, dan hakikat konstruktivisme dalam belajar matematika. Secara garis besar, prinsipprinsip konstruktivisme (Suparno, 1997, p.49) adalah sebagai berikut: (1) pengetahuan di bangun oleh siswa sendiri, baik secara personal maupun sosial, (2) pengetahuan tidak bisa dipindahkan dari guru ke murid, kecuali hanya dengan keaktifan murid sendiri untuk menalar, (3) murid aktif mengkonstruksi terus menerus, sehingga selalu terjadi perubahan konsep menuju konsep yang lebih rinci, lengkap serta sesuai dengan konsep ilmiah, (4) guru sekedar membantu menyediakan sarana dan situasi agar proses konstruksi siswa berjalan mulus.

Selain itu, untuk mengatasi rendahnya mutu pembelajaran di Indonesia khususnya pembelajaran matematika, salah satu pendekatan 
yang bisa digunakan guru adalah pembelajaran melalui siswa aktif. Hal ini sesuai dengan yang dinyatakan oleh Suparno, dkk (2002, p.42) bahwa banyak orang menaruh harapan atas terwujudnya pembelajaran siswa aktif. Siswa yang secara aktif terlibat dalam proses pembelajaran dicirikan oleh dua aktivitas yakni aktif dalam berpikir (minds-on) dan aktif dalam berbuat (hands-on). Kedua bentuk aktif ini saling terkait. Perbuatan nyata siswa dalam pembelajaran merupakan hasil keterlibatan berpikir terhadap obyek belajarnya. Pengalaman sebagai hasil perbuatan siswa, selanjutnya diolah dengan menggunakan kerangka berpikir dan pengetahuan yang dimilikinya untuk memba-ngun pengetahuan. Dengan cara ini siswa dapat mengembangkan pemahaman bahkan mengubah pemahaman sebelumnya menjadi semakin baik. Pemahaman baru ini, yang melalui pengolahan dan refleksi, dapat melahirkan tindakan yang lain sebagai perwujudan keingintahuannya. Dengan demikian, proses siswa aktif merupakan proses yang tiada henti.

Lebih lanjut dijelaskan bahwa agar siswa dapat terlibat aktif dalam proses pembelajaran diperlukan adanya proses pembiasaan. Pembiasaan yang bisa dilakukan di antaranya dengan problem posing dan problem solving. Problem posing dimulai dengan persoalan dalam wujud pertanyaan, maka dalam diri siswa terdapat keinginan untuk mengetahui melalui proses belajarnya. Sedangkan pada problem solving, permasalahan yang muncul dalam pembelajaran harus diselesaikan (dicari jawabannya) oleh siswa selama proses belajarnya. Tidak cukup kalau siswa hanya mahir mempersoalkan sesuatu tetapi miskin dalam mencari pemecahannya. Penyelesaian masalah sendiri dapat dilakukan secara mandiri (selfindependence learning) maupun secara kelompok (group learning). Adapun tantangan yang dihadapi siswa dalam inovasi pembelajaran salah satunya adalah siswa kehilangan motivasi dalam belajar dan mengerjakan soal matematika yang berorientasi pada HOTS (Jailani \& Retnawati, 2016, p.5).Terkait dengan kemampuan berpikir, pembelajaran matematika dengan pendekatan problem posing dan pendekatan problem solving merupakan pendekatan yang tepat untuk digunakan (Silver, 1997, p.75). Selain itu, pembelajaran dengan pendekatan problem posing dan pendekatan problem solving juga dapat digunakan untuk memicu sikap matematis siswa (Marsigit, 2009, p.9). Bahkan pendekatan pembelajaran problem posing dan problem solving dikatakan sebagai inti dari pendidikan matematika (Christou et al, 2005, p.149).

Dalam pembelajaran matematika dengan pendekatan problem posing ini, siswa diharapkan membuat atau mengajukan pertanyaan sendiri sesuai dengan permasalahan yang dihadapi sehari-hari yang berkaitan dengan materi yang sedang dipelajari untuk diselesaikan sendiri oleh siswa tanpa harus dijawab langsung oleh guru. Menurut Suryosubroto (2009, p.203) "salah satu pendekatan pembelajaran yang dapat memotivasi siswa untuk berpikir kritis sekaligus dialogis, kreatif dan interaktif yakni problem posing atau pengajuan masalah-masalah yang dituangkan dalam bentuk pertanyaan" dalam hal ini siswa diberikan kesempatan untuk menyampaikan ide-ide yang dimiliki baik secara individu atau kelompok.

Hal ini juga sesuai dengan pendapat Johnson (2007, p.215) mengatakan bahwa problem posing merupakan bagian penting dari berpikir kreatif, begitu juga berpikir terbuka. Ketika kita dengan netral meneliti ide-ide tidak lazim yang mungkin berlawanan dengan keyakinan kita, kita mengisi imajinasi kita. Ketika kita membuka diri dengan pengalamanpengalaman baru, kita menemukan cara baru untuk melihat.

Selain pendekatan problem posing, dalam pembelajaran inkuiri dikenal juga pendekatan problem solving. Corkcroft (Khalid, 2007, p.173) mengatakan bahwa problem solving adalah alat untuk mengembangkan kemampuan berpikir matematis dan dikatakan bahwa kemampuan menyelesaikan masalah (problem solving ability) sebagai jantung dari matematika. Lebih lanjut Khalid mengatakan bahwa mengajarkan matematika melalui penyelesaian masalah adalah satu cara untuk membuat siswa lebih memahami pelajaran dan memotivasi siswa untuk berpikir kritis. Hal ini juga didukung oleh pernyataan Husni (2014, p. 14) bahwa pemecahan masalah merupakan pendekatan yang sangat penting dalam pembelajaran matematika karena selain meningkatkan ketekunan, keingintahuan, kepercayaan diri juga dapat memfokuskan diri pada metode atau langkah dalam memecahkan masalah.

Haylock dan Thangata (2007, pp.145146), menyatakan bahwa pemecahan masalah terjadi ketika seseorang menggunakan cara berpikir matematis dan melakukan penalaran untuk menutup kesenjangan antara kenyataan 
yang terjadi dengan apa yang diharapkan. Jadi, dalam menyelesaikan masalah dibutuhkan kreativitas untuk berpikir secara ilmiah dan menggunakan penalaran yang logis. Menurut Polya (1973, pp.5-6), ada empat langkah dalam problem solving yaitu: memahami masalah, merencanakan penyelesaian, menyelesaiakan masalah, dan melihat kembali.

Berdasarkan latar belakang masalah tersebut, penelitian ini bertujuan untuk mendeskripsikan dan membandingkan keefektifan pembelajaran matematika dengan problem posing dan problem solving ditinjau dari ketercapaian kompetensi dasar, metode matematis, dan sikap matematis siswa SMA Negeri 1 Sakra Lombok Timur. Terkait dengan tujuan penelitian dan kajian teori maupun penelitian yang relevan, pada penelitian ini diajukan hipotesis (1) pembelajaran matematika dengan pendekatan problem posing dan problem solving efektif ditinjau dari ketercapaian kompetensi dasar, metode matematis, dan sikap matematis siswa SMA; (2) pembelajaran matematika dengan pendekatan problem solving lebih efektif dari problem posing ditinjau dari ketercapaian kompetensi dasar, metode matematis, dan sikap matematis siswa SMA.

\section{METODE}

Penelitan ini menggunakan metode eksperimen semu (quasiexperiment) karena peneliti menggunakan kelompok yang telah terbentuk secara alami, sehingga individu tidak dipilih secara acak atau without random assignment (Creswell, 2013, p.242).Rancangan eksperimen yang digunakan adalah pretestposttest with nonequivalent Group Design. Secara skematis, rancangan eksperimen yang digunakan dalam penelitian ini adalah sebagai berikut.

\begin{tabular}{l} 
Kelompok A $\mathrm{T}_{1}$----- $\mathrm{X}_{1^{-----}} \mathrm{T}_{2}$ \\
\hline Kelompok B $\mathrm{T}_{1}$----- $\mathrm{X}_{2^{-----}} \mathrm{T}_{2}$ \\
\hline
\end{tabular}

Gambar 1. Pretest-posttest, Nonequivalent group design

Keterangan

$\mathrm{T}_{1}$ : Pretest kelas problem posing dan kelas problem solving

$\mathrm{T}_{2}$ : Posttest kelas problem posing dan kelas problem solving

$\mathrm{X}_{1}$ : Penerapan pendekatan problem posing

$\mathrm{X}_{1}$ : Penerapan pendekatan problem solving
Penelitian ini dilakukan di SMA Negeri 1 Sakra Kabupaten Lombok Timur NTB yang dilaksanakan dari bulan Mei-Juni 2013 sebanyak 10 kali pertemuan.Populasi penelitian ini adalah seluruh siswa kelas X SMAN 1 Sakra Lombok Timur NTB tahun pelajaran 2012/2013 yang terdiri dari tujuh kelas. Sampel dalam penelitian ini adalah dua kelas dari tujuh kelas itu yang dipilih secara acak sebagai kelas ekperimen. Kelas yang terpilih adalah kelas X-6 dan kelas $\mathrm{X}-7$. Dari dua kelas yang terpilih, dilakukan pengundian untuk menentukan pendekatan pembelajaran yang akan digunakan pada masing-masing kelas. Berdasarkan hasil pengundian, kelas X-6 terpilih sebagi kelas problem posing dan kelas X-7 sebagai kelas problem solving.

Variabel dalam penelitian ini ada dua jenis yaitu variabel bebas dan varibel terikat. Varibael bebas terdiri dari pembelajaran matematika dengan pendekatan problem posing dan pendekatan problem solving. Sedangkan varibel terikat dalam penelitian ini adalah keefektifan pembelajaran yang terdiri dari ketercapaian kompetensi dasar, metode matematis, dan sikap matematis siswa SMA.

Teknik pengumpulan data dalam penelitian ini adalah tes tertulis berbentuk uraian berupa pretest, posttest, dan angket yang diberikan sebelum dan sesudah dilakukan treatment.Instrumen yang digunakan dalam pengumpulan data berupa tes dan non tes. Tes digunakan untuk mengukur ketercapaian kompetensi dasar dan metode matematis siswa, sedangkan non tes berupa angket digunakan untuk mengukur sikap matematis siswa SMA.

Instrumen divalidasi dengan teknik expert judgment yaitu meminta pertimbangan ahli terkait dengan validasi isi. Instrumen dinilai valid dan dinyatakan layak digunakan dengan beberapa revisi.Selanjutnya dilakukan validitas konstruk (construct validity) untuk mengukur trait atau konstruk teoretik. Untuk memperoleh bukti validitas konstruk khususnya untuk instrumen non tes (sikap matematis siswa), dilakukan uji coba. Data yang diperoleh dari hasil uji coba tersebut dianalisis dengan Factor Analysis. Analisis dilakukan dengan bantuan SPSS 16for Windows.

Hasil analisis faktor sebagai uji persyaratan analisis diperoleh Kaiser-MeyerOlkin Measure of Sampling Adequacy (KMO) sebesar 0,560. Nilai yang diperoleh ini lebih besar dari 0,5 sehingga analisis faktor dapat dilanjutkan. Pada analisis terdapat 34 item yang 
dimasukkan dan diperoleh sepuluh faktor yang mempunyai eigen value lebih besar dari 1, artinya banyaknya faktor sikap matematis siswa adalah sepuluh faktor.

Kesepuluh faktor itu memiliki eigenvalues sebagai berikut: faktor 1 dengan eigenvalues 7,387; faktor 2 dengan eigenvalues 3,320: faktor 3 dengan eigenvalues 2,670; faktor 4 dengan eigenvalues 2,376; faktor 5 dengan eigenvalues 1,888; faktor 6 dengan eigenvalues 1,671; faktor 7 dengan eigenvalues 1,442 ; faktor 8 dengan eigenvalues 1,227; faktor 9 dengan eigenvalues 1,131; dan faktor 10 dengan eigenvalues 1,060. Dengan demikian, kesepuluh faktor itu mampu menjelaskan 71,094 $\%$ varians untuk variabel sikap matematis siswa SMA.

Untuk instrumen tes, untuk mencari indeks reliabilitas digunakan rumus Alpha Cronbach. Adapun rumus Alpha Cronbach (Ebel \& Frisbie, 1986, p.79) yang digunakan yaitu:

$$
r=\frac{k}{k-1}\left[1-\frac{\sum s_{i}^{2}}{s_{t}^{2}}\right]
$$

Keterangan:

$r=$ koefisien reliabilitas

$k=$ jumlah butir tes

$\sum s_{i}^{2}=$ jumlah varian skor tiap-tiap butir tes

$s_{t}^{2}=$ varian skor total

Hasilperhitungan koefesien reliabilitas pada kelas problem posing dengan menggunakan rumus Alpha Cronbach diperoleh bahwa koefesien reliabilitas ketercapaian kompetensi dasar, metode matematis, dan sikap matematis siswa yaitu berturut-turut 0,$667 ; 0,829$; dan 0,779 . Sedangkan pada kelas problem solving diperoleh koefesien reliabilitas ketercapaian kompetensi dasar, metode matematis, serta sikap matematis siswa secara berurutan 0,$604 ; 0,770$; dan 0,8599 .

Dataketercapaian kompetensi dasar dan metode matematis siswa diperoleh melalui pengukuran dengan instrumen tes yang berbentuk uraian. Skor yang diperoleh selanjutnya dikonversi sehingga menjadi nilai dengan rentang antara 0 sampai dengan 100. Skor tersebut kemudian digolongkan dalam kriteria berdasarkan kriteria ketuntasan minimal (KKM)yang ditetapkan oleh sekolah untuk mata pelajaran matematika yaitu 65. Nilai KKM ini digunakan untuk menentukan persentase banyak siswa yang mencapai kriteria ketuntasan tersebut. Adapun keefektifan pembelajaran matematika pada aspek afektif yaitu sikap matematis siswa ditetapkan rata-rata siswa mencapai skor lebih dari 113.

Teknik analisis data yang digunakan pada penelitian ini adalah statistik uji one sample $t$ test,two-group MANOVA, dan independet sample t-test dengan menggunakan SPSS 16.0 for windows. Analisis one sample t-test ini dilakukan untuk mengetahui efektif tidaknya pendekatan problem posing dan pendekatan problem solving pada masing-masing variabel dependen yaitu ketercapaian kompetensi dasar, metode matematis, dan sikap matematis siswa. Data yang dianalisis dengan one sample t-test ini adalah data yang diperoleh dari posttestdan angket matematis siswasetelah treatment. Secara umum hipotesis statistik yang di uji yaitu sebagai berikut:

$\mathrm{H}_{\mathrm{o}}: \mu \leq \mu_{0}, \quad \mathrm{H}_{\mathrm{a}}: \quad \mu>\mu_{0}$ dengan taraf signifikansi $\alpha=0,05$

Statistik one sample t-test dirumuskan sebagai: $t=\frac{\bar{x}-\mu_{0}}{s / \sqrt{n}}$

Keterangan :

$\bar{x}$ : rata-rata sampel

$\mu_{0}$ : rata-rata yang ditetapkan

$s$ :varian sampel

$n$ : banyaknya anggota sampel

kriteria keputusan yaitu tolak $\mathrm{H}_{0}$ jika $t$ hitung

$>t_{\alpha ; n-1}$

Untuk variabel ketercapaian kompetensi dasar danmetode matematis siswa SMA, nilai $\mu_{o}$ pada rumus di atas adalah 65 skala 0 - 100. Nilai ini ditentukan berdasarkan pertimbangan bahwa KKM yang ditetapkan untuk mata pelajaran matematika di SMAN 1 Sakra Lombok Timur adalah 65, sehingga peneliti menetapkan 65 sebagai standar untuk menentukan efektif tidaknya pendekatan problem posing dan pendekatan problem solvingyang diterapkan ditinjau dari ketercapaian kompetensi dasar dan metode matematis siswa SMA.

Adapun untuk variabel dependen sikap matematis siswa nilai $\mu_{o}=113$. Nilai ini ditentukan berdasarkan pertimbangan bahwa keriteria sikap matematis siswa pada kategori baik, sehingga peneliti menetapkan 113 sebagai standar untuk menentukan efektif tidaknya pendekatan problem posing dan pendekatan problem solvingyang diterapkan ditinjau dari sikap matematis siswa SMA.

Setelah melakukan analisis dengan one sample t-test, analisis dilanjutkan dengan multivariate two-group test dengan bantuan 
program SPSS16.0for windows. Teknik analisis ini digunakan untuk melihat adanya perbedaan vektor mean antara dua kelompok yaitu kelompok yang menggunakan pendekatan problem posing dan problem solving dengan tiga variabel dependen yaitu ketercapaian kompetensi dasar, metode matematis, dan sikap matematis siswa secara simultan.

Untuk analisis dengan two-group MANOVA, data yang dianalisis adalah data yang diperoleh dari pretest, posttest, dan angket sikap matematis siswa sebelum dan setelah treatment. Secara umum hipotesis statistik yang akan diuji sebagai berikut:

$$
\begin{gathered}
\mathrm{H}_{0}:\left(\begin{array}{l}
\mu_{11} \\
\mu_{21} \\
\mu_{31}
\end{array}\right)=\left(\begin{array}{l}
\mu_{12} \\
\mu_{22} \\
\mu_{32}
\end{array}\right) \\
\mathrm{H}_{\mathrm{a}}:\left(\begin{array}{l}
\mu_{11} \\
\mu_{21} \\
\mu_{31}
\end{array}\right) \neq\left(\begin{array}{l}
\mu_{12} \\
\mu_{22} \\
\mu_{32}
\end{array}\right)
\end{gathered}
$$

Pada penelitian ini variabel yang diteliti adalah ketercapaian kompetensi dasar, metode matematis, dan sikap matematis siswa dengan pendekatan problem posingdan pendekatan problem solving maka penjelasan dari hipotesis diatas menjadi:

$H_{0}$ : Tidak terdapat perbedaan vektor rata-rata antara pembelajaran matematika dengan pendekatan problem posingdan pendekatan problem solving ditinjau dari ketercapaian kompetensi dasar, metode matematis, dan sikap matematis siswa SMA.

$H_{a}$ : terdapat perbedaan vektor rata-rata antara pembelajaran matematika dengan pendekatan problem posingdan pendekatan problem solving ditinjau dari ketercapaian kompetensi dasar, metode matematis, dan sikap matematika siswa SMA.

Hipotesis diatas diuji dengan taraf signifikansi $\alpha=0,05$. Statistik uji two-group MANOVA dirumuskan sebagai berikut (Stevens, 2009, p.176):

$$
T^{2}=\frac{n_{1} n_{2}}{n_{1}+n_{2}}\left(\bar{y}_{1}-\bar{y}_{2}\right)^{\prime} S^{-1}\left(\bar{y}_{1}-\bar{y}_{2}\right)
$$

Keterangan:

$\mathrm{T}^{2} \quad=\mathrm{T}^{2}$ Hotelling's

$\mathrm{n}_{1} \quad=$ banyak subjek pada kelompok

pertama

$\mathrm{n}_{2}=$ banyak subjek pada kelompok kedua

$\left(\bar{y}_{1}-\bar{y}_{2}\right)=$ selisihmean vektor

$\mathrm{S}^{-1} \quad=$ invers matriks kovarian

Setelah diperoleh nilai $T^{2}$ Hotelling's, kemudian ditransformasikan untuk memperolah nilai distribusi $\mathrm{F}$ dengan menggunakan formula:
$F=\frac{n_{1}+n_{2}-p-1}{\left(n_{1}+n_{2}-2\right) p} T^{2}$

Dimana $=3$ adalah banyaknya variabel dependen.

Kriteria keputusan yaitu tolak $\mathrm{H}_{0}$ jika $\mathrm{F}$ hitung $>\mathrm{F}$ tabel $\left(F_{0.05, d k_{1}, d k_{2}}\right)$ derajat bebasnyad $k_{1}=p=3$ dan $d k_{2}=n_{1}+n_{2}-$ $p-1=n_{1}+n_{2}-4$. Pengujian dilakukan dengan bantuan SPSS 16.0 for windows dengan kriteria keputusannya yaitu tolak $\mathrm{H}_{0}$ jika $p$ value $<0,05$.

Jika pada uji kesamaan vektor rata-rata pada setiap kelompok diperoleh perbedaan yang signifikan maka uji selanjutnya adalah independet sample t-test untuk menguji pendekatan mana yang lebih efektif ditinjau dari ketercapaian kompetensi dasar, metode matematis, dan sikap matematis siswa. Secara umum hipotesis yang akan diuji adalah sebagai berikut:

$\mathrm{H}_{0}: \mu_{1} \leq \mu_{2}$ dan $\mathrm{H}_{\mathrm{a}}: \mu_{1}>\mu_{2}$

Keterangan:

$\mu_{1}$ : rata-rata kelompok dengan pendekatan problem posing

$\mu_{2}$ : rata-rata kelompok dengan pendekatan problemsolving

dengan taraf signifikansi $\frac{\alpha}{p}$ dengan $p=3$,

jadi untuk $\alpha=5 \%$ untuk masing-masing ttestdigunakan kriteria $\frac{0,05}{2}=0,025$. Statistik uji yang digunakan adalah:

$t=\frac{\bar{y}_{1}-\bar{y}_{2}}{\sqrt{S^{2}\left(\frac{1}{n_{1}}+\frac{1}{n_{2}}\right)}}$ dengan

$s^{2}=\frac{\left(n_{1}-1\right) s_{1}^{2}+\left(n_{2}-1\right) s_{2}^{2}}{n_{1}+n_{2}-2}$

Keterangan:

$\bar{y}_{1}$ : nilai rata-rata sampel dengan pendekatan problem posing

$\bar{y}_{2}$ : nilai rata-ratasampel dengan pendekatan problem solving

$s_{1}^{2}$ : varian sampel dengan pendekatan problem posing

$s_{2}^{2}$ : varian sampel dengan pendekatan problem solving

$n$ :jumlahanggota sampel

Kriteria keputusan yaitu tolak $\mathrm{H}_{0}$ jikat $t_{\text {hitung }}>t_{\text {tabel }}$ atau $\left(t>t_{0,025, n 1+n 2-2}\right)$.

Beberapa asumsi yang harus dipenuhi sebelum melakukan uji hipotesis adalah asumsi normalitas dan asumsi homogenitas. Uji normalitas multivariat bertujuan untuk mengetahui apakah data berdistribusi normal atau tidak. 


\section{Pythagoras, 11 (2), Desember 2016 - 130}

Ahmad Nasrullah, M. Marsigit

Pada uji normalitas multivariat pada variable-variabel dependen masing-masing kelompok, pemeriksaan normalitas multivariat dilakukan dengan cara membuat scatter plot dari $d_{i}^{2}$ dan $q_{i} d_{i}^{2}=\left(y_{i}-y\right)^{\prime} S^{-1}\left(y_{i}-y\right)$ dimana $y_{i}$ adalah pengamatan ke-i dan $S^{-1}$ adalah invers matrik kovarian S. Kemudian $d_{i}^{2}$ diurutkan dari kecil ke besar, selanjutnya dibuat plot $d_{i}^{2}$ dengan nilai $q_{i}$ yang didekati dengan $\chi_{0.05}^{2}\left(\frac{n-i+1 / 2}{n}\right)$, dimana $\mathrm{i}=1,2, \ldots \mathrm{n}$ dan dengan derajat kebebasan $v=p$, dengan $p=3$ yaitu banyaknya variabel terikat. Kriteria keputusan yang digunakan adalah jika sekitar 50\% data mempunyai nilai $d_{j}^{2}<\chi^{2}$ (jarak kuadrat kurang dari chi-kuadrat) maka data berdistribusi normal multivariat (Johnson \& Wichern, 2007, p.186). Uji normalitas multivariat ini dilakukan secara manual dengan menggunakan bantuan Microsoft Excel 2010.

Uji homogenitas dimaksudkan untuk mengetahui vaarians dari kedua kelompok eksperimen homogen atau tidak. Uji homogenitas yang dilakukan pada penelitian ini adalah uji homogenitas multivariat dan uji homogenitas univariat. Uji homogenitas multivariat bertujuan untuk mengetahui homogenitas matriks varian kovarians dua kelompok dengan tiga variabel dependen secara simultan dilakukan melalui uji homogenitas Box's $M$, menggunakan bantuan softwareSPSS 16.0 for windows. Uji homogenitas dan penarikan kesimpulan terhadap uji hipotesis dilakukan pada taraf signifikansi 0,05. Pedoman pengambilan keputusan uji homogenitas sebagai berikut: 1) jika nilai signifikansi atau nilai probabilitas kurang dari 0,05 maka dapat disimpulkan datatidak berasal dari populasipopulasi yang mempunyai matrik varians kovarian yang homogen.

\section{HASIL DAN PEMBAHASAN}

Data hasil tes ketercapaian kompetensi dasar, metode matematis, dan sikap matematis siswa pada kelas problem posing dan kelas problem solving terdiri atas data sebelum dan sesudah treatment.

\section{Analisis Data Sebelum Treatment}

Secara ringkas, hasil tes ketercapaian kompetensi dasar, metode matematis, dan sikap matematissebelum perlakuan pada kedua kelas disajikan sebagai berikut.

Tabel 2. Data Pretest Kelas Problem Posing

\begin{tabular}{lccc}
\hline \multicolumn{1}{c}{ Deskripsi } & KD & MM & SM \\
\hline Rata-rata & 43,86 & 42,48 & 112,82 \\
Standar deviasi & 7,03 & 9,39 & 9,83 \\
Nilaimaksimum & 65 & 61 & 132 \\
Nilaiminimum & 32 & 28 & 94 \\
\hline
\end{tabular}

Tabel 3. Data Pretest Kelas Problem Solving

\begin{tabular}{lccc}
\hline \multicolumn{1}{c}{ Deskripsi } & KD & MM & SM \\
\hline Rata-rata & 47,15 & 41,99 & 111,47 \\
Standar deviasi & 7,37 & 9,74 & 10,62 \\
Nilaimaksimum & 62 & 69 & 139 \\
Nilaiminimum & 29 & 25 & 93 \\
\hline
\end{tabular}

Sebelum data pretest dianalisis, terlebih dahulu akan dilakukan uji normalitas multivariat dan uji homogenitas multivariat terhadap data sebelum dilakukan perlakuan.Hasil uji normalitas multivariat data pretest dengan menggunakan bantuan Microsoft Excel 2010diperoleh data sebagai berikut.

Tabel 4. Persentase Banyak $d_{j}^{2}<\chi^{2}$ untuk Data Pretest

\begin{tabular}{lcccc}
\hline \multicolumn{1}{c}{ Kelas } & $\begin{array}{c}\text { Banyak } \\
\text { Siswa }\end{array}$ & $\begin{array}{c}\text { Banyak } \\
\boldsymbol{d}_{\boldsymbol{j}}^{2}<\boldsymbol{\chi}^{\mathbf{2}}\end{array}$ & $\boldsymbol{\%}$ & Ket \\
\hline $\begin{array}{l}\text { Problem } \\
\begin{array}{l}\text { Posing } \\
\text { Problem }\end{array}\end{array}$ & 34 & 15 & $44,12 \%$ & Normal \\
Solving & 34 & 19 & $55,88 \%$ & Normal \\
\hline
\end{tabular}

Berdasarkan Tabel 4, terlihat bahwa persentase siswa dengan nilai $d_{i}^{2}<\chi_{0,5(p)}^{2}$ menunjukkan $44,12 \%$ untuk kelas problem posing dan 55,88\% untuk kelas problem solving. Persentase untuk masing-masing kelompok menunjukkan kisaran $40 \%$ sampai 60 $\%$ sehingga dapat disimpulkan bahwa masingmasing kelompok memenuhi asumsi normalitas multivariat.

Uji homogenitas multivariat dilakukan dengan uji Box's M test menggunakan bantuan software SPSS 16.0 for windows. Hasil uji homogenitas menunjukkan nilai 0,615 . Nilai ini lebih besar dari 0,05 sehingga dapat disimpulkan bahwa matriks varians-kovarians kelompok problem posing dan problem solving adalah homogen.

Setelah memenuhi kriteria normalitas multivariat dan homogenitas multivariat, selanjutnya akan dilakukan uji hipotesis multivariat. Pengujian hipotesis multivariat pada data pretest bertujuan untuk mengetahui apakah kelompok problem posing dan kelompok problem solving berangkat dari keadaan awal yang sama. 
Berdasarkan hasil analisis data pretest dengan menggunakan SPSS 16.0 for windowsdiperoleh angka signifikansi 0,051. Jika dikaitkan dengan kriteria penerimaan, angka signifikansi > 0,05, maka $\mathrm{H}_{0}$ diterima.Karena itu dapat disimpulkan bahwa rata-rata ketercapaian kompetensi dasar, metode matematis, dan sikap matematis siswa kelas Problem Posingtidak berbeda dengan rata-rata ketercapaian kompetensi dasar, metode matematis, dan sikap matematis siswa kelas Problem Solving, atau dengan kata lain kondisi awal subjek penelitian pada kelas problem posing dan problem solving ditinjau dari ketercapaian kompetensi dasar, metode matematis, dan sikap matematis siswa adalah sama

\section{Analisis Data Setelah Treatment}

Secara ringkas, hasil tes ketercapaian kompetensi dasar, metode matematis, dan sikap matematis setelah perlakuan pada kedua kelas disajikan sebagai berikut.

Tabel 5. Data Posttest Kelas Problem Posing

\begin{tabular}{lccc}
\hline \multicolumn{1}{c}{ Deskripsi } & KD & MM & SM \\
\hline Rata-rata & 70,33 & 74,01 & 122,85 \\
Standar deviasi & 8,73 & 12,48 & 11,76 \\
Nilaimaksimum & 88 & 97 & 143 \\
Nilaiminimum & 50 & 42 & 98 \\
\hline
\end{tabular}

Tabel 6. Data Posttest Kelas Problem Solving

\begin{tabular}{lccc}
\hline \multicolumn{1}{c}{ Deskripsi } & KD & MM & SM \\
\hline Rata-rata & 77,68 & 79,58 & 120,85 \\
Standar deviasi & 7,97 & 9,5 & 13,59 \\
Nilaimaksimum & 97 & 100 & 151 \\
Nilaiminimum & 62 & 56 & 97 \\
\hline
\end{tabular}

Sebelum data pretest dianalisis, terlebih dahulu akan dilakukan uji normalitas dan uji homogenitas terhadap data setelah dilakukan perlakuan. Uji normalitas mencakup normalitas multivariat dan normalitas univariat. Begitu juga halnya asumsi homogenitas mencakup homogenitas multivariat dan homogenitas univariat.

Hasil uji normalitas multivariat data pretest dengan menggunakanMicrosoft Excel 2010 diperoleh data sebagai berikut.

Tabe17. Persentase Banyak $d_{j}^{2}<\chi^{2}$ untuk Data Posttest

\begin{tabular}{lcccc}
\hline Kelas & $\begin{array}{c}\text { Banya } \\
\mathbf{k} \\
\text { Siswa }\end{array}$ & $\begin{array}{c}\text { Banyak } \\
\boldsymbol{d}_{\boldsymbol{j}}^{2}<\chi^{\mathbf{2}}\end{array}$ & $\boldsymbol{\%}$ & Ket \\
\hline $\begin{array}{l}\text { Proble } \\
m\end{array}$ & 34 & 18 & $\begin{array}{c}52,94 \\
\%\end{array}$ & $\begin{array}{c}\text { Norma } \\
1\end{array}$ \\
\hline
\end{tabular}

\begin{tabular}{lcccc}
\hline $\begin{array}{l}\text { Posing } \\
\text { Proble }\end{array}$ & & & & \\
$m$ & 34 & 18 & 52,94 & Norma \\
Solving & & & $\%$ & 1 \\
\hline
\end{tabular}

Berdasarkan Tabel 7, terlihat bahwa persentase siswa dengan nilai $d_{i}^{2}<\chi_{0,5(p)}^{2}$ pada kelas problem posingdan kelas problem solving menunjukkan 52,94\%. Persentase ini berkisar antara $40 \%$ sampai $60 \%$ sehingga dapat disimpulkan bahwa masing-masing kelompok memenuhi asumsi normalitas multivariat.

Uji homogenitas multivariat dilakukan dengan uji Box's $\mathrm{M}$ test menggunakan bantuan software SPSS 16.0 for windows. Hasil uji homogenitas menunjukkan nilai 0,342 . Nilai ini lebih besar dari 0,05 sehingga dapat disimpulkan bahwa matriks varians-kovarians kelompok problem posing dan problem solving adalah homogen.

Selanjutnya sebelum uji hipotesis univariat, terlebih dahulu akan dilakukan uji asumsi normalitas univariat dan homogenitas univariat. Hasil uji normalitas pada data univariat dapat dilihat dari hasil signifikansi kolmogorov-smirnov dengan menggunakan bantuan softwareSPSS 16.0 for windows. Berikut adalah output hasil pengujian asumsi normalitas.

Tabel 8. Hasil Uji Asumsi Normalitas Univariat

\begin{tabular}{lcccc}
\hline \multirow{2}{*}{\multicolumn{1}{c}{ Variabel }} & \multicolumn{3}{c}{ Kolmogorov- } & \multirow{2}{*}{ Ket } \\
\cline { 2 - 4 } & Stat & Df & Sig. & \\
\hline Ketercapaian KD & 0,980 & 68 & 0,292 & Normal \\
Metode & 0,773 & 68 & 0,589 & Normal \\
$\begin{array}{l}\text { Matematis } \\
\text { Sikap Matematis }\end{array}$ & 0,891 & 68 & 0,406 & Normal \\
\hline
\end{tabular}

Berdasarkan Tabel 8, terlihat bahwa pada masing-masing variabel dependen memiliki nilai signifikansi yang lebih besar dari 0,05. Dengan demikian dapat disimpulkan bahwa normalitas masing-masing variabel dependen sudah terpenuhi.

Homogenitas varians dapat dilihat dari hasil levene's test menggunakan bantuan software SPSS 16.0 for windows. Hasil output SPSS untuk uji homogenitas menggunakan data pretes adalah sebagai berikut.

Tabe19. Hasil Uji Asumsi Homogenitas Varians

\begin{tabular}{lccc}
\hline \multicolumn{1}{c}{ Variabel } & F & Sig. & Keterangan \\
\hline Ketercapaian KD & 0,096 & 0,758 & Homogen \\
Metode Matematis & 0,030 & 0,863 & Homogen \\
Sikap Matematis & 0,430 & 0,514 & Homogen \\
\hline
\end{tabular}


Berdasarkan Tabel 9, dapat dilihat bahwa nilai signifikansi levene's test untuk ketiga variabel dependen masing-masing lebih dari taraf nyata 0,05 . Dengan demikian dapat disimpulkan bahwa pada taraf nyata 0,05 varians kedua kelas homogen pada setiap variabel dependen.

\section{Keefektifan Pendekatan Pembelajaran}

Analisis keefektifan masing-masing pendekatan pembelajaran ditinjau dari ketercapaian kompetensi dasar, metode matematis maupun sikap matematis siswa SMA digunakan one sample t test.

Dari hasil analisis menggunakanSPSS 16.0 for windows, ketercapaian kompetensi dasar pada kelas problem posing diperoleh $t_{\text {hitung }}=3,560$ dengan nilai signifikansi 0,001 . Sedangkan pada kelas problem solving diperoleh $t_{\text {hitung }}=9,280$ dengan nilai signifikansi 0,000.Jika dikaitkan dengan kriteria pengujian dengan nilai signifikansi 0,05 , maka $\mathrm{H}_{0}$ untuk kedua kelom-pok ditolak. Jadi, dapat disimpulkan bahwa pembelajaranmatematika dengan pendekatanproblem posing dan problem solving efektif ditinjau dari ketercapaian kompetensi dasar.

Berdasarkan kriteria ketuntasan yang telah ditetapkan dan hasil uji one sample t-test, diperoleh kesimpulan bahwa pembelajaran matematika dengan pendekatan problem posingefektif ditinjau dari ketercapaian kompetensi dasar, metode matematis, dan sikap matematis siswa SMA. Hasil penelitian ini sesuai dengan hasil penelitian yang dilakukan Yuniati (2010) yang mana siswa yang memperoleh pembelajaran dengan problem posing mengalami peningkatan kemampuan pemahaman dan penalaran matematika lebih baik dari siswa yang mendapatkan pembelajaran konvesional.

Keefektifan pendekatan pembelajaran problem posing kemungkinan besar disebabkan oleh karakterisitik dari pendekatan pembelajaran ini yaitu menyediakan kesempatan kepada siswa untuk mengajukan masalah mereka. Hal ini sejalan dengan yang diungkapkan oleh Lavy\& Shriki (2007, p.129) bahwa salah satu keunggulan yang dimiliki olek pendekatan pembelajaran matematika dengan pendekatan problem posing adalah menyediakan kesempatan kepada siswa untuk mengajukan masalah mereka. Hal ini bisa memicu kemampuan berpikir beragam dan fleksibel, serta meningkatkan kemampuan pemecahan masalah. Selain itu, menurut (Kusnaeni \& Retnawati, 2013, p.41) dalam hasil penelitiannya bahwa pembelajaran dengan pendekatan problem posing dapat memancing siswa untuk menemukan pengetahuan yang bukan diakibatkan dari ketidaksengajaan melainkan melalui upaya siswa untuk mencari hubungan-hubungan dalam informasi yang dipelajarinya.

Hasil penelitian ini sesuai dengan yang dikatakan oleh Khalid (2007, p.173) bahwa mengajarkan matematika melalui problem solving adalah salah satu cara untuk membuat siswa lebih memahami pelajaran, dan memotivasi siswa untuk berpikir kritis. Pernyataan ini sejalan dengan penjelasan Sanjaya (2011, pp.220-221) bahwa di antara keunggulan pembelajaran dengan pendekatan problem solving adalah problem solving dapat meningkatkan aktivitas pembelajaran siswa dan merupakan teknik yang cukup bagus untuk lebih memahami isi pelajaran.

Hasil analisis metode matematis siswa dengan menggunakan SPSS 16.0 for windows pada kelas problem posing diperoleh $\mathrm{t}_{\text {hitung }}=4$, 208 dengan nilai signifikansi 0,000. Adapun pada kelas problem solving diperoleh $t_{\text {hitung }}=$ 8,948 dengan nilai signifikansi 0,000 . Dengan kriteria pengujian pada taraf signifikansi $0,05 \mathrm{H}_{0}$ ditolak. Jadi dapat disimpulkan bahwa pembelajaran matematika dengan pendekatan problem posing dan problem solving efektif ditinjau dari metode matematis siswa SMA.

Hasil penelitian ini sesuai dengan penelitian yang dilakukan oleh Kusnaeni \& Retnawati $(2013$, p.42) yang menyatakan bahwa penerapan pendekatan problem posing dalam setting kooperatif tipe TAI lebih efektif dibandingkan dengan pendekatan konvensiponal ditinjau dari kemampuan komunikasi dan pemecahan masalah matematis. Hasil penelitian ini dikuatkan oleh Lavy \& Shriki (2007, pp.129130) yang menyatakan bahwa di antara keunggulan pendekatan pembelajaran problem posing adalah memicu kemampuan berpikir beragam dan fleksible, meningkatkan kemampuan pemecahan masalah, dan meningkatkan kemampuan bernalar dan refleksi.

Hasil penelitian di lapangan menunjukkan baik pendekatan problem posing maupun problem solving, sama-sama efektif untuk mengembangkan kemampuan berpikir khususnya pada aspek metode matematis. Ini sesuai dengan teori sebagaimana yang dinyatakan oleh 
Silver (1997, p.75) bahwa pendekatan problem posing dan problem solving bisa membantu siswa mengembangkan kemampuan berpikir matematis.

Selanjutnya hasil analisis sikap matematis siswa pada kelas problem posingdiperoleh $t_{\text {hitung }}$ $=4,886$ dengan nilai signifikansi 0,000. Sedangkan pada kelas problem solving sikap matematis siswa diperoleh $t_{\text {hitung }}=3,371$ dengan nilai signifikansi 0,002.Jika dikaitkan dengan kriteria pengujian dengan nilai signifikansi 0,05 , maka $\mathrm{H}_{0}$ ditolak. Jadi dapat disimpulkan bahwa pembelajaran matematika dengan pendekatan problem posing dan problem solving efektif ditinjau darisikap matematis siswa. Hasil penelitian ini mendukung hasil penelitian yang telah dilakukan oleh Sardin (2015, p. 194) bahwa pembelajaran problem solving efektif ditinjau dari prestasi belajar, kemampuan penalaran siswa, dan sikap siswa terhadap matematika.

Hal ini sesuai dengan pernyataan Lavy\& Shriki (2007, p.129) yang menyebutkan bahwa di antara keunggulan yang terdapat dalam pembelajaran dengan pendekatan problem posing adalah menumbuhkan rasa kepemilikan siswa dalam mengkonstruksi pengetahuan mereka sendiri. Sebagai rasa kepemilikan ini adalah adanya ketertarikan dan minat, serta antusias dalam proses belajar mengajar matematika.

Keefektifan pendekatan pembelajaran problem solving ditinjau dari sikap matematis siswa kemungkinan besar disebabkan karena pada pendekatan pembelajaran ini adanya kesempatan pada siswa untuk mengaplikasikan pengetahuan yang mereka miliki dalam dunia nyata sehingga pembelajaran problem solving dianggap lebih menyenangkan dan lebih disukai siswa, serta dapat mengembangkan minat siswa untuk secara terus menerus belajar sekalipun belajar pada pendidikan formal telah berakhir sebagaimana yang dikatakan oleh Sanjaya (2011, pp.220-221). Hal ini Ini sesuai dengan pernyataan Haylock \& Thangata (2007, pp.147148) bahwa hasil positif dari pengalaman sukses menyelesaikan masalah dalam problem solving adalah adanya rasa puas yang terjadi ketika masalah itu dapat diselesaikan, hal ini akan membuat percaya diri siswa akan bertambah dan akan berkontribusi terhadap sikap positif siswa terhadap matematika.

Hasil penelitian di lapangan menunjukkan baik pendekatan problem posing maupun problem solving, sama-sama efektif untuk mengembangkan sikap matematis siswa. Selain hasil penelitian di lapangan, secara teoretis pendekatan problem posing dan problem solving juga dapat memicu sikap matematis siswa. Marsigit (2009, p.9) mengatakan bahwa sikap matematis siswa dapat dipicu melalui pembelajaran problem posing dan problem solving.

\section{Perbedaan Keefektifan Pendekatan Pembelajaran}

Keefektifan pendekatan pembelajaran ditinjau dari ketiga variabel dependen secara serentak dilakukan pengujian hipotesis dengan MANOVA (Multivariate Analysis of Varians).

Berdasarkan uji Hotelling's Trace diperoleh nilai signifikansi 0,003 . Nilai ini lebih kecil dari 0,05 sehingga pada taraf nyata 0,05 $\mathrm{H}_{0}$ ditolak. Jadi, dapat disimpulkan bahwa ada perbedaan keefektifan pembelajaran dengan pendekatan problem posing dan problem solving ditinjau dari ketercapaian kompetensi dasar, metode matematis, dan sikap matematis siswa SMA Negeri 1 Sakra Lombok Timur.

Untuk mengetahui pendekatan pembelajaran manakah yang lebih efektif ditinjau dari masing-masing variabel dependen, akan dilakukan uji hipotesis dengan independent sample t-test untuk menjawab rumusan masalah berikutnya.

Hasil perhitungan manual yang dilakukan pada variabel ketercapaian kompetensi dasar menghasilkan nilai $t=3,6027$. Sedangkan $t_{\text {tabel }}=t_{(\alpha, v)}=t_{(0,05,66)}=1,997$. Karena $t_{\text {hitung }}>t_{\text {tabel }}$, maka dapat disimpulkan bahwa pembelajaran matematika dengan pendekatan problem solving lebih efektif dibandingkan dengan pendekatan problem posing ditinjau dari ketercapaian kompetensi dasar.

Hasil perhitungan manual metode matematis yang dilakukan menghasilkan nilai $t$ $=$ 2,571. Sedangkan $t_{\text {tabel }}=t_{(\alpha, v)}=$ $t_{(0,05,66)}=1$,997. Karena $t_{\text {hitung }}>t_{\text {tabel }}$, maka dapat disimpulkan bahwa pembelajaran matematika dengan pendekatan problem solvinglebih efektif dibandingkan dengan pendekatan problem posingditinjau dari metode matematis siswa SMA.

Selanjutnya akan dilakukan analisis untuk membandingkan pendekatan problem posing dan problem solving ditinjau dari sikap matematis. Hasil perhitungan manual yang dilakukan menghasilkan nilai $t=0,649$. 
Sedangkan $t_{\text {tabel }}=t_{(\alpha, v)}=t_{(0,05,66)}=1,997$. Karena $t_{\text {hitung }}<t_{\text {tabel }}$, maka dapat disimpulkan bahwa pembelajaran matematika dengan pendekatan problem solving tidak lebih efektif dibandingkan dengan pendekatan problem posingditinjau dari sikap matematis siswa SMA. Hasil penelitian ini sesuai dengan penelitian yang dilakukan oleh Husni (2014, p.20) bahwa penerapan pendekatan problem posing tidak lebih baik daripada problem solving ditinjau dari prestasi belajar dan curiosity siswa terhadap matematika.

\section{SIMPULAN DAN SARAN}

\section{Simpulan}

Hasil penelitian menunjukkan bahwa (1) pendekatan problem posing dan problem solving efektif ditinjau dari ketercapaian kompetensi dasar, metode matematis, dan sikap matematis siswa SMA, (2) ada perbedaan keefektifan pendekatan problem posing dan problem solving ditinjau dari ketiga variabel dependen, (3) pendekatan problem solving lebih efektif dibandingkan dengan pendekatan problem posing ditinjau dari ketercapaian kompetensi dasar dan metode matematis, (4) tidak ada perbedaan keefektifan kedua pendekatan pembelajaran ditinjau dari sikap matematis siswa SMA.

\section{Saran}

Pendekatan pembelajaran problem posing dan problem solving efektif ditinjau dari ketercapaian kompetensi dasar, metode matematis, dan sikap matematis siswa SMA. Oleh karena itu, disarankan kepada guru untuk menggunakan pembelajaran dengan pendekatan problem posing dan pendekatan problem solvingsebagai alternatif dalam pembelajaran matematika khususnya yang terkait dengan usaha meningkatkan ketercapaian kompetensi dasar, metode matematis, dan sikap matematis siswa SMA. Selain itu, disarankan kepada peneliti lain agar memperluas materi yang digunakan dalam penelitian, sehingga memungkinkan generalisasi yang lebih luas. Dalam menerapkan pembelajaran dengan pendekatan problem posing dan pendekatan problem solving, guru sebaiknya dapat mempersiapkan bahan ajar, LKS, alat dan bahan serta rencana pembelajaran yang memberi kesempatan lebih luas kepada siswa untuk mengeksplorasi pengetahuannya secara mandiri.

\section{DAFTAR PUSTAKA}

Christou, C. et al. (2005). An empirical taxonomy of problem posing processes. ZDM 2005 Volume 37 (3).

Creswell, J. W. (2013). Research design: qualitative, quantitative, and mixed methods approaches (third edition). (Terjemahan Ahmad Fawaid \& Khoirul Anam). Yogyakarta: Pustaka Pelajar.

Ebel, R. I.\& Frisbie, D. A. (1986). Essencial of educational measurement. $\left(4^{\text {th }}\right.$ ed) New Jersey, NJ: Prentice-Hell, Inc.

Haylock, D., \& Thangata, F. (2007). Key concept in teaching primary mathematics. California, CA: SAGE Publication.

Husni, M. A. (2014). Keefektifan pembelajaran matematika dengan problem posing dan problem solving ditinjau dari prestasi dan curiosity. PYTHAGORAS: Jurnal Pendidikan Matematika, 9(1), 11-21.

Jailani \& Retnawati, H. (2016). The challenges of junior high school mathematic teachers in implementing the problem-based learning for improving the higher-order thinking skills. The Online Journal of Counseling and Education, 5(3), 1-13.

Johnson, E. B. (2007). Contextual teaching and learning. (Terjemahan Ibnu Setiawan). Bandung: Mizan Learning Center.

Johnson, R.A. \& Wichern, D.W. (2007). Applied multivariate statistical analysis. Upper Saddle River, NJ: Pearson Education.

Katagiri, S. (2007). Mathematical thinking and how to teach it. Diambil tanggal 10 November 2012, dari http://home.kku.ac.th/crme/APEC/PDF\%2 02004

Kemendiknas. (2003). Undang-Undang RI nomor 20, Tahun 2003, tentang Sistem Pendidikan Nasional.

Kemendiknas. (2005). Peranturan Pemerintah nomor 19, Tahun 2005, tentang Standar Nasional Pendidikan.

Kemendiknas. (2006). Peraturan Menteri Pendidikan Nasional nomor 22, Tahun 2006, tentang Standar Isi.

Khalid, M. (2007). Incorporating mathematical thinking in addition and subtraction of fraction: Real issues and challenges. 


\section{Pythagoras, 11 (2), Desember 2016 - 135}

Ahmad Nasrullah, M. Marsigit

Diambil tanggal 10 November 2012 dari http://www.crme.kku.ac.th/APEC/PDF\%2 02007/Madihah\%20 Khalid.pdf.

Kusnaeni, K. \& Retnawati, H. (2013). Problem posing dalam setting kooperatif tipe TAI ditinjau dari kemampuan komunikasi dan pemecahan masalah. PYTHAGORAS: Jurnal Pendidikan Matematika, 8(1), 3343. Retrieved from http://journal.uny.ac.id/index.php/pythago ras/article/view/8492.

Lavy, I. \& Shriki, A. (2007). Problem posing as a means for developing mathematical knowledge of prospective teachers. Makalah disajikan pada Proceedings of the $31^{\text {th }}$ Conference of The International Group for the Psychology of Mathematics Education, di Oranim Academic College of Education.

Marsigit. (2007).Mathematical thinking across multilateral culture. Makalah disajikan dalam Seminar Nasional Pembelajaran Matematika Sekolah, di Universitas Negeri Yogyakarta.

Marsigit. (Desember 2009). Pembudayaan matematika di sekolah untuk mencapai keunggulan bangsa. Makalah disajikan dalam Seminar Nasional Pembelajaran Matematika Sekolah, di Universitas Negeri Yogyakarta.

Marsigit. (Juli 2011). Developing the attitude and creativity in mathematics education. Makalah disajikan dalam The International and The Fourth National Conference on Mathematics, di Universitas Negeri Yogyakarta.

Polya, G. (1973). How to solve it: A new aspect of mathematical method. Princeton, NJ: Princeton University Press.
Sanjaya. (2011). Strategi pembelajaran berorientasi standar proses. Jakarta: Prenada Media.

Sardin. (2015). Perbandingan keefektifan pembelajaran guided inquiry dan problem solving ditinjau dari prestasi belajar peluang, kemampuan penalaran, dan sikap siswa terhadap matematika. PYTHAGORAS: Jurnal Pendidikan Matematika, 10(2), 189-200. doi:http://dx.doi.org/10.21831/pg.v.10i2.9 158.

Silver, E.A. (1997). Fostering creativity through instruction rich in mathematics problem solving and problem posing. Diambil pada tanggal 2 Agustus 2012, dari http:/www.emis.de.

Stacey, K. (2007). What is mathematical thinking and why is it important?. Center for Research on International in Educational Development. University of Tsukuba.

Stevens, J. P. (2009). Applied multivariate statistics for the social sciences $\left(5^{\text {th }} \mathrm{ed}\right)$. New York \& London: Routledge Taylor \& Francis Group.

Suparno, P. (1997). Filsafat konstruktivisme dalam pendidikan. Yogyakarta: Kanisius.

Suparno, P., Rohandi, Sukadi, Kartono. (2002). Reformasi pendidikan, sebuah rekomendasi. Yogyakarta: Kanisius.

Suryosubroto. (2009). Proses belajar mengajar di sekolah. Jakarta: Rineka Cipta.

Yuniati, S. (2010). Meningkatkan kemampuan pemahaman dan penalaran matematik siswa sekolah menengah pertama dengan pembelajaran problem posing. Tesis Magister, tidak diterbitkan, Universitas Pendidikan Indonesia, Bandung. 